\title{
NIIISE⿹
}

criteria for a recommended standard . . . . occupational exposure to

\section{HYDROGEN SULFIDE}
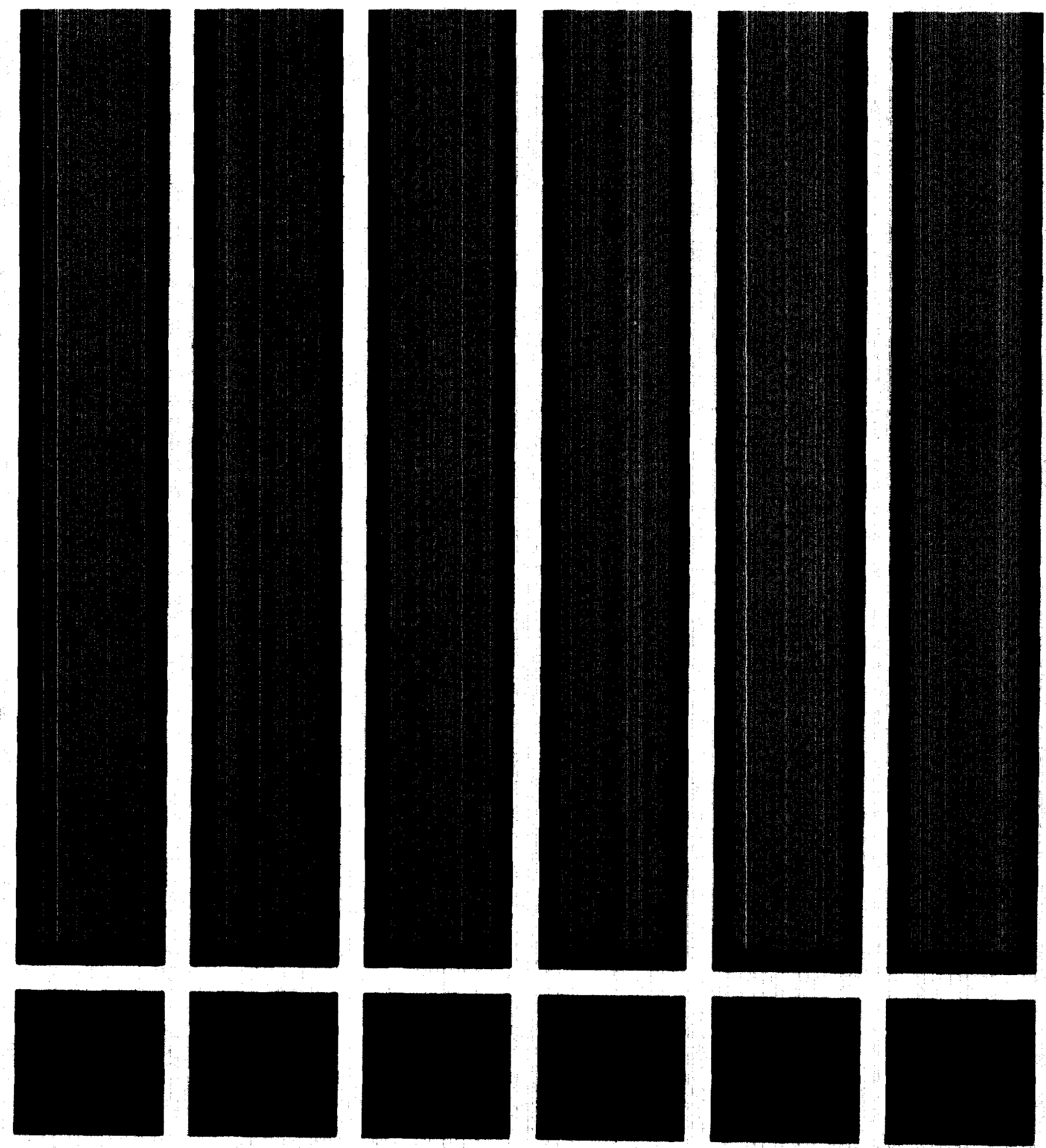

U.S. DEPARTMENT OF HEALTH, EDUCATION, AND WELFARE

Public Health Service

Center for Disease Control

National Institute for Occupational Safety and Health 


\section{criteria for a recommended standard....}

\section{OCCUPATIONAL EXPOSURE \\ TO \\ HYDROGEN SULFIDE}

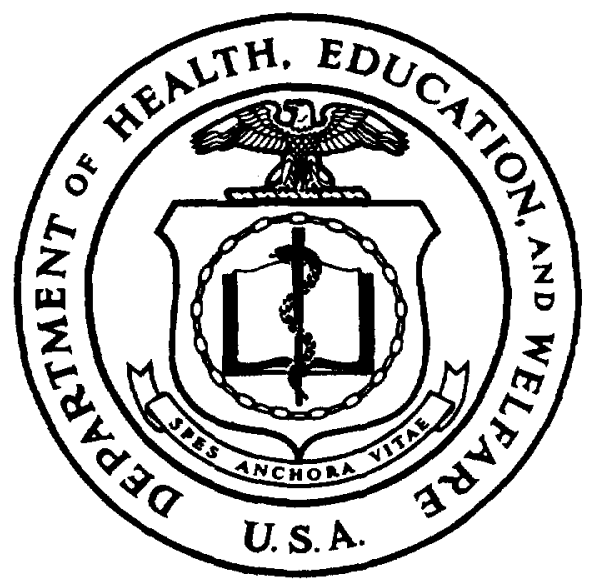

U.S. DEPARTMENT OF HEALTH, EDUCATION, AND WELFARE Public Health Service

Center for Disease Control

National Institute for Occupational Safety and Health MAY 1977 
DHEW (NIOSH) Publication No. 77-158 
PREFACE

The Occupational Safety and Health Act of 1970 emphasizes the need for standards to protect the health and provide for the safety of workers exposed to an ever-increasing number of potential hazards at their workplace. The National Institute for Occupational Safety and Health has projected a formal system of research, with priorities determined on the basis of specified indices, to provide relevant data from which valid criteria for effective standards can be derived. Recommended standards for occupational exposure, which are the result of this work, are based on the health effects of exposure. The Secretary of Labor will weigh these recommendations along with other considerations such as feasibility and means of implementation in developing regulatory standards.

It is intended to present successive reports as research and epidemiologic studies are completed and as sampling and analytical methods are developed. Criteria and standards will be reviewed periodically to ensure continuing protection of the worker.

I am pleased to acknowledge the contributions to this report on hydrogen sulfide by members of the NIOSH staff and the valuable constructive comments by the Review Consultants on Hydrogen Sulfide, by the ad hoc committees of the American Academy of Industrial Hygiene and the American Occupational Medical Association, and by Robert B. O'Connor, M.D., 
NIOSH consultant in occupational medicine. The NIOSH recommendations for standards are not necessarily a consensus of all the consultants and professional socleties that reviewed this criteria document on hydrogen sulfide. A list of Review Consultants appears on page vi.

\author{
John P. Amklea, H.D. \\ John F. Finklea, M.D. \\ Director, National Institute for \\ Occupational Safety and Health
}


The Division of Criteria Documentation and Standards Development, National Institute for Occupational Safety and Health, had primary responstbility for development of the criterla and recommended standard for hydrogen sulfide. The division review staff for this document consisted of J. Henry Wills, Ph.D., Chairman, Howard C. McMartin, M.D., Douglas L. Smith, Ph.D., and Paul E. Caplan, with Kenneth J. Kronoveter (Division of Surveillance, Health Evaluations, and Field Studies), Charles S. McCammon, Jr. (Division of Physical Sciences and Englneering), and Howard C. Spencer (consultant). Stanford Research Institute (SRI) developed the basic information for consideration by NIOSH staff and consultants under contract No. CDC-99-74-31. Herbert $L$. Venable served as criteria manager.

The views expressed and conclusions reached in this document, together with the recommendations for a standard, are those of NIOSH, after reviewing the evidence and considering the comments of reviewers; these views and conclusions are not necessarily those of the consultants, other federal agencles, and professional societies, or of the contractor. 


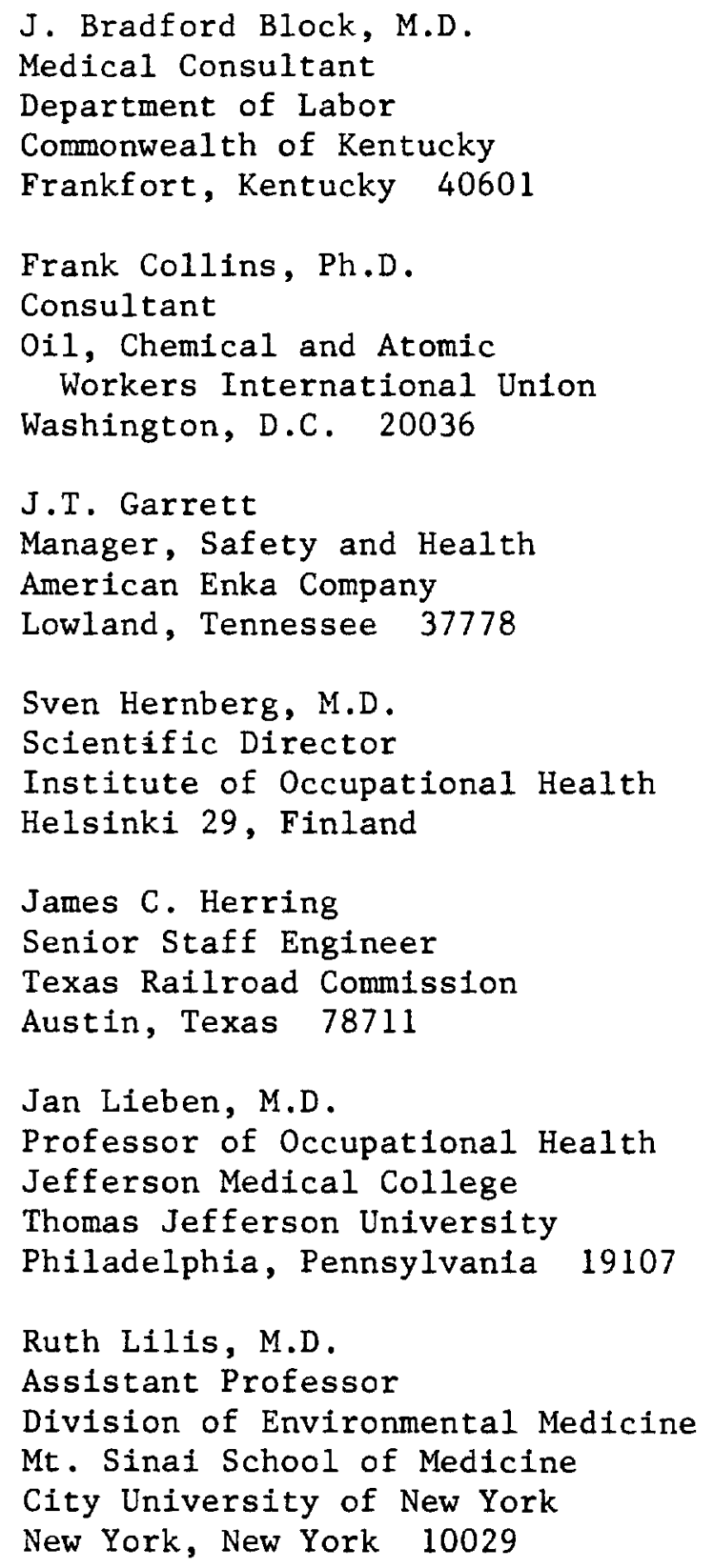


REVIEW CONSULTANTS ON HYDROGEN SULFIDE (CONTINUED)

\author{
Mars Y. Longley, Ph.D. \\ Manager, Industrial Hygiene and Toxicology \\ Standard of Ohio 011 Company \\ Cleveland, Ohio 44115 \\ Robert A. Neal, Ph.D. \\ Director \\ Center for Environmental Toxicology \\ Department of Biochemistry \\ School of Medicine \\ Vanderbilt University \\ Nashville, Tennessee 37202 \\ Fred S. Venable \\ Senior Industrial Hygienist \\ Exxon Company, USA \\ Baton Rouge, Louisiana 70821
}


CRITERIA DOCUMENT:

RECOMMENDATIONS FOR AN OCCUPATIONAL

EXPOSURE STANDARD FOR HYDROGEN SULFIDE

Contents

PREFACE

iii

REVIEW CONSULTANTS ON HYDROGEN SULFIDE

vi

I. RECOMMENDATIONS FOR A HYDROGEN SULFIDE STANDARD 1

Section 1 - Environmental (Workplace Air) 2

Section 2 - Medical

Section 3 - Labeling and Posting

3

Section 4 - Personal Protective Equipment 7

Section 5 - Informing Employees of Hazards from Hydrogen Sulfide 10

Section 6 - Work Practices 10

Section 7 - Sanitation 15

Section 8 - Monitoring and Recordkeeping Requirements 15

$\begin{array}{ll}\text { II . INTRODUCTION } & 19\end{array}$

III. BIOLOGIC EFFECTS OF EXPOSURE 22

Extent of Exposure $\quad 22$

Historical Reports 23

Effects on Humans $\quad 27$

Epidemiologic Studies $\quad 40$

Animal Toxicity $\quad 44$

Correlation of Exposure and Effect 57

$\begin{array}{ll}\text { Carcinogenicity, Mutagenicity, Teratogenicity, } & \\ \text { and Effects on Reproduction } & 60\end{array}$

IV. ENVIRONMENTAL DATA 65

Environmental Concentrations $\quad 65$

Control of Exposure 66

Environmental Sampling and Analytical Methods 68

$\begin{array}{ll}\text { Biologic Monitoring } & 78\end{array}$

V. WORK PRACTICES $\quad 79$ 
VI. DEVELOPMENT OF STANDARD 86

Basis for Previous Standards 86

Basis for the Recommended Standard 89

VII. RESEARCH NEEDS 98

$\begin{array}{ll}\text { VIII. REFERENCES } & 100\end{array}$

IX. APPENDIX I - Air Sampling Method for Hydrogen Sulfide 113

X. APPENDIX II - Analytical Method for Hydrogen Sulfide 118

XI. APPENDIX III - Hydrogen Sulfide Monitors 128

XII. APPENDIX IV - Material Safety Data Sheet 133

XIII. APPENDIX V - NIOSH Interim Work Practice Recommendations 143

$\begin{array}{lll}\text { XIV. TABLES AND FIGURE } & 147\end{array}$ 